\section{The Right Hon. J. Ramsay MacDonald, F.R.S.}

The sudden death of Mr. Ramsay MacDonald from heart failure, on Tuesday night, at seventy-one years of age, while on a voyage to South America, will be deeply regretted by his many friends in scientific circles. He left England on November 4 for a three months' holiday, which he described as "the first he had ever had free from care", and a wireless message stating that he passed away on November 9, at 8.45 p.m., was received a few hours later.

Mr. MacDonald's last speech in public was made at the Royal Institution on October 22, when he delivered the Radford Mather lecture of the British Association on "Science and the Community". The main part of this discourse was published in NATURE of Oetober 30, and it is of melancholy interest to record that the same issue contained personal appreciations of the work and influence of his friend, Lord Rutherford, to whom he referred in terms of affectionate regard in his lecture.

As a young man, Mr. MacDonald was a keen student of science, and it was through the accident of circumstances that his interests were diverted into social and political fields. When he went to Bristol more than fifty years ago, to take charge of a boys' club, his ambition was to become a science teacher, and he took particular interest in geology. It happened, however, that he came into contact with a very remarkable group of social reformers in Bristol at that time and soon associated himself with their movement. Even when he left Bristol to come to London he continued his studies of scientific subjects at the Birkbeck College and privately with the view of obtaining a scholarship or exhibition upon successful results in the old Science and Art Depart. ments examinations. It was impossible, however, for him to find sufficient time for the intensive study required, outside his daily working hours, to prepare himself for one of the scholarships then tenable at the Normal School of Science, South Kensington, now the Royal College of Science, and he had to abandon his early hopes.

It was through his social work that Mr. MacDonald became associated with the daughter of Dr. J. H. Gladstone, F.R.S., the distinguished chemist, and niece of Lord Kelvin, and they were married in 1896. They worked together for social reform in complete sympathy until Mrs. MacDonald's death in 1911; one of their two sons is Mr. Malcolm MacDonald, Secretary of State for Dominion Affairs.

After Mr. MacDonald had resigned his office as Prime Minister and First Lord of the Treasury in 1935, he became Lord President of the Council, and as such was responsible to Parliament for the reports of the Department of Scientific and Industrial Research, in the work of which he took particular interest. He was elected a fellow of the Royal Society in 1930 under the special rule which provides for the election of a limited number of persons who "have rendered conspicuous service to the cause of science". $\mathrm{He}$ was elected a member of Parliament for the Scottish Universities in 1936 and held this seat at the time of his death. This is not the place to survey his political career or his influence as a statesman, but we are glad to express grateful appreciation of the encouragement he always gave to scientific work and to record the esteem in which his memory is cherished in scientific circles.

\section{Prof. E. J. Rapson, F.B.A.}

WE regret to record the death of Prof. E. J. Rapson, professor of Sanskrit in the University of Cambridge, which took place suddenly at Cambridge on October 3, at the age of seventy-six years.

Edward James Rapson, the son of the Rev. E. Rapson, vicar of West Bradley, Somerset, was born on May 12, 1861, and was educated at Hereford Cathedral School and St. John's College, Cambridge, where he was elected a classical foundation scholar in 1883. He studied Sanskrit under Cowell and Bendal, taking a first class in the Classical Tripos of 1883 and the Indian Languages Tripos two years later. He was awarded the Brotherton Sanskrit scholarship in 1885 and the Le Bas prize in 1886, and was elected to a fellowship at St. John's in the following year. In the same year he became librarian of the Indian Institute, Oxford, where he was associated with the then Boden professor, Sir Monier Monier-Williams. A few months later he joined the staff of the British Museum, taking charge of the collection of Indian coins. In 1903 he was appointed professor of Sanskrit in University College, I,ondon, and in 1906 went to Cambridge, where he occupied the chair in Sanskrit until his retirement in 1936 , when he was accorded the title of emeritus professor.

Pre-eminent as scholar and teacher in Sanskrit, it was through palæography and numismatics, and more especially the numismatics of the early Indian dynasties, that Rapson made his outstanding con. tributions to Indian studies. When he joined the staff of the British Museum, knowledge of the early history of India was largely a blank. It was in great part owing to his studies that this gap has been filled to no little extent. Of this the evidence will be found in his "Indian Coins" (1897), his contributions to the British Museum catalogue of Indian coins, and his communications in the Numismatic Chronicle, of which he was editor, the Journal of the Royal Asiatic Society, and other scientific and learned periodicals. His abilities as scholar and historian found wider scope as editor of the first two volumes of the "Cambridge History of India". The first volume, on Ancient India, to which he himself contributed four chapters, was published in 1922; but the secondis still uncompleted, though the later volumes have appeared.

WE regret to announce the following deaths :

Prof. H. B. Fantham, Strathcona professor of zoology in McGill University, Montreal, since 1933, professor of zoology and comparative anatomy in the University of the Witwatersrand, Johannesburg, in 1917-32, on October 27, aged sixty years.

Dr. J. A. Voeleker, C.I.E., consulting chemist to the Royal Agricultural Society of England, on November 6, aged eighty-three years. 